\title{
ARTISTIC SELF-REFLECTION AS THE MECHANISM OF LITERATURE SELF-CONSCIOUSNESS IN THE CONTEXT OF TRANSITIONAL ARTISTIC THINKING
}

\section{Shtepenko 0 .}

\section{INTRODUCTION}

The literary self-reflection is a universal mechanism traditionalizing the achievements of literature, renewing the artistic paradigm, and at the same time it is a perspective of comprehension of cultural crises and aesthetic changes. The coverage of this phenomenon in the Modern and Postmodern literature allows choosing it as a consideration aspect of the dynamics and vectors of literary search, especially in the transitional epochs, marked by the change of ideological and aesthetic guidelines as well as established scientific reception methods of art

Writer's self-knowledge is closely connected with the complex of global philosophical, cultural and aesthetic problems; it reflects the changes of world images, human concepts and the dynamics of artistic thinking types. The unceasing process of meta-description in literature has some insufficiently studied rhythms, forms and strategies, the definition and description of which is a relevant problem, becoming more acute at the crucial stages of literature development.

Self-reflection acquired a distinctive intensity in the $20^{\text {th }}$ century that allowed R. Barthes to characterize this period as "an age of reflections on what is literature ${ }^{1 »}$. The process covered many national literatures and was reflected in well-known works, acknowledged as the classics of the $20^{\text {th }}$ century. As stated by O. Keba, the landmark works of the $20^{\text {th }}$ century were written according to "a meta-textual pattern, characterized by the framework narratives and narrators' attempts to comprehend the essence of the narration, the specifics of the storytelling process itself and its impact on listeners ${ }^{2}$,.

\section{Scientific reception of self-reflection as a mechanism of literature self-consciousness: basic approaches and research hypotheses}

Due to the full scale of the process of self-reflection in $20^{\text {th }}$ century literature, scholars propose to choose this phenomenon as a prism to consider the concept of “chaos” of the literature transitional state. Thus, M. Abasheva

${ }^{1}$ Барт Р. Литература и метаязык / Ролан Барт // Избранные работы: Семиотика. Поэтика / [Пер. с фр. С.Н. Зенкина; сост., общ. ред. и вступ. ст. Г.К. Косикова]. - М.: Прогресс, 1994. - С. 132.

${ }_{2}^{2}$ Кеба А.В. Метатекст, метароман и проблема отношения искусства к действительности в литературе XX века / А.В. Кеба // Поетика художніх форм у сучасному сприйнятті. Науковий збірник. - Одеса: Одеський національний університет імені I.I. Мечнікова: «Астропринт», 2012. - С. 13-14. 
notes that the image of the modern literature development is so complicated, "that trying to find unifying beginnings in the multidirectional dynamics of the masses that make up literature seems, at first sight, almost hopeless. Probably it is because the center of the painting has shifted beyond its frame, to the unsteady boundary between art and life, to the point that unites these beginnings - to artist's personality ${ }^{3,}$.

There are several approaches to the study of the writer's self-consciousness dynamics that differ by the perspective of the problem consideration. The most extensive one is the study of the writer's self-determination in stable and transitional times. The narrower one is the relationship between author's identity and the requirements and guidelines of style systems, and the formation of aesthetic ideals, that concretizes the interpretation of the problem of studying the writer's self-identification in a limited period and in a certain subcultural environment (for example, the least studied in the named aspect are the Russian foreign countries literature of the third wave, the Underground of the Soviet period, the work of young writers of the 1990-2000s).

Consideration of the borderline age through the prism of the search for a new literary identity and the correlation of literature self-reflection with crisis processes has a dual and mutual effect in the specific nature of creativity. The author, according to the aesthetics, is initially a transitional figure: "The characteristics of transitivity distinguish the very nature of artistic consciousness. Interpreting creativity process as an act of self-improvement allows one to see in the activity of an artist of any historical epoch the ability to go beyond himself, beyond the borders of this world. In such an aspect, any creative act can be judged as an extension of being, the creation of a fundamentally new reality, which exceeds in its expressiveness the contents of an already adapted world $\langle\ldots\rangle$. The transitivity of artist's consciousness is manifested in the desire to look beyond the limits of the already familiarized, to exceed in every new creative motion not only the established matrix, but also yourself of the yesterday. The consciousness transitivity is revealed in the effort to invent a new expressive language of art, in the ability to be a tuning fork, an expression of important states of culture, including not yet fully realized ones ${ }^{4,}$ (the italics of the author - A.Sh.). It is probable that for this reason in the crisis periods, during the world-view and aesthetic paradigms change, the author's role grows significantly in the society self-awareness, in the search of a new, personal and collective identity.

3 Абашева М.П. Литература в поисках лица (Русская проза конца XX века: становление авторской идентичности) / Марина Петровна Абашева. - Пермь: Изд-во Пермского университета, 2001. - С. 7.

4 Кривцун О.А. Смысл творчества в интерпретации художника XX века (Знаки переходного сознания) / О.А. Кривцун // Переходные процессы в русской художественной культуре: Новое и новейшее время / Отв. ред. Н.А. Хренов; Гос. ин-т искусствознания МК РФ; Науч. совет «История мировой культуры» РАН. - М.: Наука, 2003. - С. 423. 
Using this approach, the most fruitful were the studies of the transitional periods at the turns of the $17^{\text {th }}-18^{\text {th }}$ and $19^{\text {th }}-20^{\text {th }}$ centuries. In our opinion, several aspects can be distinguished in the treatment of this problem. The first one is the study of the transition mechanism, effective during all development stages, that significantly influences the content and forms of authors' selfidentification. The second one is the attempts to identify the most representative models of self-identification, character to all literatures in periods of crisis disturbances. The third one is the disclosure of the national originality in implementation of both transition mechanisms and models of writer's identity. The fourth one is the description of self-reflection peculiar types and forms.

Within the framework of the general mechanism, it is recorded the change of the world image in the transitional era and the change of the identification guidelines for all members of the society, and not only for writers. The crossroad arises, the one at which, as A. Panchenko states, Russian writer found himself at the late $17^{\text {th }}$ and early $18^{\text {th }}$ centuries, moreover, in the context of general social upheavals, the emergence of new social roles and strategies, and the review of established hierarchies: "He was a new figure in the Moscow society, and he was "out of places". He received the tonsure, but he did not abide monk's subordination. He <...> dared to neglect the patriarch himself, because he wanted to create freely, without the ecclesiastical authority "certification". But the highest degree of freedom for a loyal Moscow national of the $17^{\text {th }}$ century was direct, unquestionable dependence on the tsar. This is, of course, concerns someone who did not intend to break ties with the community. Otherwise, there were other ways, such as an open struggle with official culture - the way of Habakkuk; going to the beautiful desert, to the old men, to foolishness, to revelers, or to rebellion; and after all the escape from Russia the way of Grishka Otrepyev, Tymofej Ancudinov",'. The transitional epoch itself brings to the fore this second part of the alternative, that does not fit into the stable world image and the system protected by state mechanisms.

Thus, culture because of the recurrence of crises developed overcoming, "experiencing" mechanisms, which, in their turn, were reflected in literature, and realized in it. According to scientists, the specificity of such mechanisms for all members of the society, and for the writer especially, usually consists in actualization of the "archetypical level of psychology", which allows to find the interpretation of "chaos" of changes ${ }^{6}$ [Hrenov 2002: 159]. In addition, the society attention is focused on the "rebellious periphery" (according to Yu. Lotman), because it has not previously been included in the status world image, persecuted "outcasts", "heretics", "artists" (for example, V. Ivanov in

\footnotetext{
5 Панченко А. Русская культура в канун петровских реформ / А. Панченко. - Л.: Наука, Ленинградское отделение, 1984. - С. 183.

${ }^{6}$ Хренов Н.А. Культура в эпоху социального хаоса / Н.А. Хренов. - М.: Едиториал УРCC, 2002. - С. 159.
} 
the article "Churlenic and the Problem of the Synthesis of the Arts" characterized the place and role of a brilliant artist who does not fit into stable cultural paradigms) ${ }^{7}$.

Appealing to the figures of the $20^{\text {th }}$ century Russian literature, M. Hrenov describes the transitivity mechanisms and the specific mentality of the crisis epoch, the actualization of a spontaneous beginning in it: "It can be assumed that such a marginal figure is directly linked to the archetypical level of psyche, the activity of which prevents it from finding his place in the society, correlative to the stable world image. However, a different situation arises during the chaos period when a crisis of collective identity occurs. In particular, the collective unconscious seeks to replace the ideology that gives the world image unity. Therefore, a marginal figure of a thinker or an artist as a carrier of the collective unconscious is able to be found in the center of collective moods. Values popularized by the marginal personality type can be involved in the process of forming a new collective identity. In such situations, the attention is focused on some thinkers and artists, as happened to V. Mayakovsky, V. Meyerhold, and S. Eisenstein in the 1920s, or to A. Solzhenitsyn, A. Tarkovsky, or Yu. Lyubimov in the 1960s. ${ }^{8}$."

The revolution of the outdated center and the periphery, which conceals new possibilities, resonates with the change of the models of the author's perception by the society and with the differing from the previous artist's self-identification. "Heretic", "marginal", "outcast" are transformed into a charismatic leader, "vozhd"'. Speaking about the repetition of such a metamorphosis, M. Hrenov refers to A. Losev's famous remark that "humanistic aesthetics has become a heresy ${ }^{9, "}$. It is made the conclusion about the stability of the mechanism of the displacement of the stable center by the periphery and, consequently, about the circulation of certain models of creative self-identification: “Apparently, great artists enter the world of culture with an aura of heretics. However, over time, the heretic image is able to transform into the image of a charismatic leader who was brought the center of attention. Every single heretic is a marginal person, because he or she puts himself in opposition to the authority. His goal is connected not with the maintenance of the current order, but with its denial. Therefore, it is closer to utopia than to ideology. This circumstance puts the artist in a particular situation regarding the authorities on the one hand, and the society on the other. Obviously, at the beginning of his activity, the artist is alone and in isolation. This solitude of his is an indispensable condition for his transformation into a charismatic leader. In opposing the authorities, the marginal artist provokes in

\footnotetext{
7 Иванов В. Чурленис и проблема синтеза искусств / Иванов В. // Бездны и межи. - М. : изд-во «Мусагетъ», 1916. - С. 334.

${ }^{8}$ Хренов Н.А. Культура в эпоху социального хаоса / Н.А. Хренов. - М. : Едиториал УРCC, 2002. - C. 160.

9 Лосев А. Эстетика Возрождения / А. Лосев. - М. : «Мысль», 1978. - С. 364 
society consciousness the activation of the collective unconscious ${ }^{10,}$. By the way, this transitivity mechanism is recognized by the majority of researchers, but with an adjustment to the national culture specificity. This feature is of interest to us, first of all, in the aspect of identifying those figurative, archetypical guidelines that extend at the transitional epochs and, according to the researchers, "emerge" in the process of the authors' self-reflection, affecting their self-identification.

Thus, Yu. Lotman and B. Uspensky first hypothesized the work of the duality mechanism in Russian culture, which leads to the fact that radical changes awaken the activity of archaic, archetypes, traditional models, which have already exhausted themselves in the past, but have settled in the depths of the collective unconscious. The hypothesis was based on the study of Russian literary medieval times, the $17^{\text {th }}$ century, and it demonstrated the nonlinear nature of the dynamics; detachment from the "old" led to the reversion of even older models. As stated by the scientists, "careful consideration convinces us that the new (post-petrovskaya) culture is much more traditional than it was thought to be. The new culture was created not so much according to the schemes of the "Western" (though subjectively perceived as the "Western"), but according to the "reversed" structural plane of the old "culture ${ }^{11 "}$ ". The transitional period revives archaic models, in particular archetypes that actively functioned in the Middle Ages.

Subsequently, this idea of the inversion type of Russian culture, of two contrasting poles in it (without a center, character to the "Western" one), and the mechanism of abrupt change, the conversion of poles (but not the evolution) with the inevitable return to the "old" standards, archetypes, was picked up and developed by a number of scientists. They applied the hypothesis and methodology of study offered by Yu. Lotman and B. Uspensky to later stages of the culture dynamics in general and literature in particular. Thus, in his work M. Hrenov, bases on the samples of the Russian literature of the late $19^{\text {th }}$ - early $20^{\text {th }}$ centuries, and $\mathrm{N}$. Yastrebova gives similar responses to the whole $20^{\text {th }}$ century as a transitional one. The face of the $20^{\text {th }}$ century and its "fate", according to the researcher, are "all the same breaks, objections, instantaneous new expectations against the background of the sharp rejection of the previous ... and the hidden roots of traditions. In the foreground there is a discontinuity and renewal, in the depth there is the stability of traditional mentality structures, which seems to change the quality, but is still recognized by its archetypes ${ }^{12}$.

\footnotetext{
10 Хренов Н.А. Культура в эпоху социального хаоса / Н.А. Хренов. - М.: Едиториал УРСС, 2002. - С. 160.

${ }_{11}$ Лотман Ю. Роль дуальных моделей в динамике русской культуры (до конца XVIII века). // Ю. Лотман, Б. Успенский // Избранные труды. - М., 1994. - Т. 1. Семиотика истории. Семиотика культуры. - С. 235.

12 Ястребова Н.А. Искусство советского времени в проблемном поле европейского XX века / Н.А. Ястребова // Переходные процессы в русской художественной культуре: Новое и Новейшее время / Отв. ред. Н.А. Хренов ; Гос. ин-т искусствознания МК РФ; Научн. совет «История мировой культуры» РАН. - М.: Наука, 2003. - С.454.
} 
Important for the study of the current forms of creative self-consciousness are two hypotheses of $\mathrm{N}$. Yastrebova: the first one about the complication, the "branching" of inversion on the new turns, even "its softening,

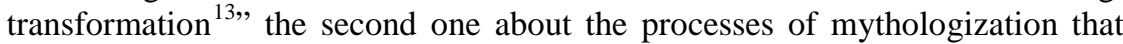
accompany the transitivity experience, as well as the reference to a certain set of identification archetypes. Here we come to the most important and not yet sufficiently solved problem - the identification of the archetypes chain by which models of self-identification are created.

\section{Interpretational models of writer's self-identification in the context of transitional artistic thinking}

Transitional thinking aims not only at the existence of such a guidelines paradigm, but also the specificity of the relations between its constituents. These relationships are sharply contrasting, they correspond to mythological oppositions (so far as the global change of the world image is interpreted), as well as they are the most dramatic.

To a certain extent, the models antinomy is predetermined by the very specificity of creativity. The inner bifurcation of the author is an immanent characteristic of him and it reflects the natural artistry of this particular psychological type. Thus, the French philosopher Jacques Maritain emphasizes the paradoxicality, the antinomic nature of the artist's inner world and of his self-identification models. Creativity is "open to both Heaven and Hell", the artist is the embodiment of both "a madman, passionate about irrational impulse, and a craftsman who subtly guides his careful mind ${ }^{14,}$. These contrasting beginnings are the most strikingly cleared up in a transitional era, with its typical contradictions, conflicts, acuteness and dynamics of feelings. Contrasting beginnings often originate from the mythological pattern. And in Russian literature, as N. Yastrebova rightly emphasizes, they arise from the medieval religious conception of "divine and devilish". Reflecting on "rupture" with the past and culture of the West during the Soviet era, the researcher states: "Inversion ... dominated there as the principle of constructing external structures of the culture picture: consciousness was divided by polar senses, and only one of them was declared "true". The other one was its antipode, a "devil" incarnate, alienated by the antithesis zone.

Modern theorists argue that this is a stable tradition of both Russian culture and mentality. The analysis should be considered to understand whether this is the case. Until then, we face a culture mythologem, constructed according to

13 Ястребова Н.А. Искусство советского времени в проблемном поле европейского XX века / Н.А. Ястребова // Переходные процессы в русской художественной культуре: Новое и Новейшее время / Отв. ред. Н.А. Хренов ; Гос. ин-т искусствознания МК РФ; Научн. совет «История мировой культуры» РАН. - М.: Наука, 2003. - С. 457.

14 Маритен Ж. Ответственность художника / Жак Маритен // Самопознание европейской культуры ХХ века. - М., 1991. - С. 196. 
this principle $<\ldots>$. As in the whole the $20^{\text {th }}$ century, there are Facade and Shadow, Myth and Reality in this whole picture. The open landscape of the day - and its underground, its shadows and its twilight. And maybe - the essence. In their turn, in the conglomerate of these subtypes and predictable beginnings are the same subconscious inversion, the pursuit of the "only true", emotional repulsion either from the Shadow, or from the Eye. At the same time, in the field of compounds (inevitable due to the objective cohesion of a dual reality, which is constantly reproduced), meaningful links of inversions have to be clarified and replenished ${ }^{15}$ ». In addition, in the transitional period, these contrasting beginnings tend to replace each other, swap on the value axis, e.g. the "outcast" and the "prophet" models.

The "prophet" / "tomfool" pair is in the same rank of antinomies, dramatized by the transitional way of thinking. Besides, each of the components of this opposition is most likely mythologized by the general scheme: in the fate or in the appearance of a particular person, one searches for a mythical sign that testifies peculiarities and indicates that he is entrusted with a higher power to change the course of events.

S. Mockovichi, reflecting on the universal culture patterns of the transitional period, insists that future charismatic leaders should always be unusual in the eyes of society, to have some physical or mental disabilities which signify they are chosen: «These people are often unbalanced, eccentric, they have deviations, a strange look, abnormal way of thinking and fragmented language. They are fanatics who, without hesitation, sacrifice their interests, comfort, even their family, often for the sake of a bizarre goal. Their position is also eccentric ${ }^{16}$ ». (Let us mention in this regard the leading meta-text of the Russian underground "Vasily Rozanov through the eyes of an eccentric" by Ven. Yerofeyev, where a bright postmodernist defines himself, as well as his like-minded predecessor, as an eccentric; this guideline is explored in detail in the second part of our monograph). M. Hrenov puts this feature - the bright marginality - into the framework of the opposition "prophet" / "tomfool" and demonstrates the inversion of the poles of interpretation and self-identification in the transitional time: "If we mean not a political leader but an artist as a bearer of charisma, then we can associate him with the tomfool, manifesting, according to V. Turner, not the values of "structure", that is, society with its social inequality, but the values of "communitas", that is, community. The image of an outcast, a stranger, can serve as the archetype of any great artist

15 Ястребова Н.А. Искусство советского времени в проблемном поле европейского XX века / Н.А. Ястребова // Переходные процессы в русской художественной культуре: Новое и Новейшее время / Отв. ред. Н.А. Хренов ; Гос. ин-т искусствознания М-ва культуры РФ; Научн. совет «История мировой культуры» РАН. - М. : Наука, 2003. - С. 457.

${ }_{16}$ Московичи С. Машина, творящая богов / Серж Московичи. - М.: Центр психологии и психотерапии, 1998. - С. 295. 
$<\ldots>{ }^{17}$ ». The researcher emphasizes that the contrast of roles causes an ambivalent attitude to such a "transitional figure", which conceptualizes both fears and recognition of mythologized superiority.

Accents and modifications of the archetypes which the transition time brings to the paradigm of guidelines are further discussed in our study. Let us outline its parameters, drawing on A. Toynbee's characterization of the culture "break" and its effect on self-identification. A. Toynbee's typology resonates with other studies of transitivity and particular stylistic systems in many respects. However it presents a complete set of guidelines, and many culture experts are influenced by it. "A Study of History" A. Toynbee contains the set of roles that an artist assumes in a situation of culture crisis: "archaist", "futurist", "hermit", "transformed" and "savior" (besides A. Toynbee, these roles were singled out by A. Panchenko in the literature of the $17^{\text {th }}$ century and Yu. Tynyanov in the art of the word of the $19^{\text {th }}$ century.).

All these guidelines are among the concepts of Russian culture, and, according to the researchers, the guideline of the "traveler" and "outcast" is also added as a specific accent ${ }^{18}$, which generally reflects the transitional character of national culture. We also note that the "savior" can be interpreted as a double to the previously mentioned "prophet": "In a civilization that collapses, the creator, having accepted the challenge, plays the role of a savior and helps society respond to the challenge that the ruling minority that has lost creative opportunities is unable to cope with $^{19}$,,

All the mentioned above guidelines have been transformed, reinterpreted by national mentality, and some of them have been rejected as inorganic. Due to the common feature of the transitional era - the struggle of "old" and "new" the "archaist" and "futurist" (or "archaist" and "innovator") are considered as the universal roles (A. Panchenko). Moreover, the "archaist" really acts as an outstanding revolutionary at times. This is how A. Panchenko characterizes the protopope Avvakum, who (in accordance with the logic of the invasion mechanism) applies the model of the behaviour of the first Christians, who suffered in the name of true faith, to his struggle with the demonized reformers.

In light of the above, the interrelated and interchangeable axes of transitional thinking of the "prophet" and "jester" guidelines proved to be the most problematic. First of all, they are characteristic of Western European cultures. Their actualization in the era of postmodernism, which received its finest, "etalon" forms precisely in Western European and American literature, is indicative in this regard. Precisely this feature - the simultaneous use and interchangeability of the roles of "priest" and "tomfool" - is, according to

17 Хренов Н.А. Культура в эпоху социального хаоса / Н.А. Хренов. - М. : Едиториал УРCС, 2002. - С.160-161ю

18 Степанов Ю. Константы: словарь русской культуры / Ю. Степанов. - Изд. 2-е испр., доп. - М. : Академический проект, 2001. - С. 181.

19 Тойнби А.Дж. Постижение истории / А.Дж. Тойнби. - М. : Айрис-Пресс, 2002. - С. 151. 
P. Kawieki, another determining feature, which makes it possible to classify postmodernism as a transition phenomenon ${ }^{20}$. It is important that such an opposition in the interpretation of the artist and his self-determination came into the Russian art of word from Western European literature, and A. Panchenko dates this episode also to the transitional $18^{\text {th }}$ century. The myth of the creator's ambivalent essence is reflected in the translated "Fatselia", where the legendary Virgil was portrayed in different texts in contrasting incarnations. Russian literature has chosen its own reading of a baroque artist, avoiding the extremes of exaltation and derision: "Prophetic intentions were strange to the Moscow laborers of the word, and even more strange and shameful seemed to them the role of the royal jester ${ }^{21}$ ”. After numerous reflections on the novelty of one's role, wins the model, which reflects the specifics of the Russian Baroque with its renaissance cheerfulness, confidence and enlightenment intentions: "The figure of the master, "intelligent man" looms between the poles of the myth about the poet, between the prophet and the tomfool. It is the desired for the "Latinists" of the $17^{\text {th }}$ century type, which can be seen in one of the poems "Vertograd multiflorous":

Дионисий мучитель некогда ярися.

Аристипп им философ ниско посадися

С досадою. Обаче мудрый осклабися, рек: О царю, то место здесь много почтися».

Тако есть воистину от начала века: место есть ради умна чесно человека ${ }^{22} »$.

Self-determination, as well as the interpretation of the creator by the contemporaries of the Russian transitional $17^{\text {th }}$ century demonstrate a large number of models, but all of them are devoid of the extreme opposition of "priest" and "tomfool". Such creative roles are realized: "teacher", "new teacher", "laborer of the word", "philosopher", "rhetorician".

We believe that the reason is that both contrasting signs of the priest / tomfool in Russian culture are in the field of attraction of the global mythological opposition of "sacral" and "infernal", since social and cultural crises are traditionally perceived through such global categories (from the Middle Ages, schism, Peter I epoch to revolutions and "perestroika"). In this context, the "tomfool" turns into a "holy fool" who either has a sacred purpose, not a secular entertaining status, or approximates a carnival culture, popular laughter, a guideline for a skomorokh, which also has sacred connotations in the Russian culture. This affiliation of the skomorokh to a sacred, not profane plan of being and, in fact, fulfillment of the priest functions were repeatedly

${ }^{20}$ Kawiecki P. Post-modernism - From Clown to Priest / P. Kawiecki // The Subjuect in Postmodernism. - Ljubljana, 1989. - Vol. 2. - P. 101.

21 Панченко А. Русская культура в канун петровских реформ / А. Панченко. - Л.: Наука, Ленинградское отделение, 1984. - С. 181.

22 Там же. С. 182. 
emphasized by researchers who noted that the skomorokh forced everyone to take part in a game, which rules were accepted due to the universal recognition of the ritual of merrymaking: «In a wonderful bylina "Vavilo and Skomorokhs" $<\ldots>$ they are called holy five times! This undoubtedly, refers not to holiness as spiritual purity and an ideal prototype of a person (sanctum), but to being sacred (sacrum), possessing some kind of magical knowledge, magical power, implementing magical functions ${ }^{23} »$. We also note that Avvakum's recoding of the word "game" in self-reception is indicative: «A мне ведь неколи плакать: всегда играю со человеки, также со страстями и похотями бьюся, окаянный $<\ldots>$ В нощи что соберу, а в день рассыплю - волен бог, да и вы со мною». In A. Panchenko's interpretation, the word "play" is targeted at a new reader of the transitional period, who does not like long sermons, Slavonic Church language; one needs to speak with him in a simple way, and Avvakum introduces into the conversation the word "play" not in the meaning, that can be learnt in church or in spiritually useful books, but in what is accepted on feasts and weddings ${ }^{24}$. But at the same time, we note that the meaning of what is said remains as high as the guideline of self-identification - "he is playing with the soul of man" and thinking of himself a pasteur and teacher, whose sermon has got a new form, including the paradoxical Avvakum's "chatter". Ritual festive "game" is correlated with the biblical catching of souls, underlining the sacral, ceremonial and missionary nature of the phenomenon. The profane, secular meanings of the reference point "tomfool" were not inculcated, as all the contemporaries felt they were the participants of the most large-scale historical revolution that awakens apocalyptic associations. In this regard, it is demonstrative the perception of this period as a mystery by the contemporaries of the transitional period of the late $17^{\text {th }}$ - early $18^{\text {th }}$ centuries, which is described by K. Isupov, and the creators in this case (as an examples of Avvakum again and his fellow campaigners) associate themselves with sacral (and not secular, "tomfool") guidelines in all extravagant actions and ideas: "The theater came to Rus in the form of a mystery in the genre composition of which we can find: 1) sacral ability of the plot ("Golgotha”), 2) sacrifice as a situational center; 3) motive of temptation / rescue. The absence of ramp, that separates the spectator and stage space, is characteristic for the mystery: all are actors and participants. But it is profoundly significant that the "school theater" and "comedy chorina" <...> were preceded by the process of materialization of the reality itself, directed by Ivan the Terrible ("oprichnina") and the initiators of the sacrificial "conflagrations" - old believers. The prisoner of the Pustozersk dungeon felt similar to that of the early Christian martyrs and acted accordingly; “яко инок в пещи огненной, предстоял своим неправым обвинителям

${ }^{23}$ Панченко А. Русская культура в канун петровских реформ / А. Панченко. - Л.: Наука, Ленинградское отделение, 1984. - С. 73.

${ }^{24}$ Там же. С. 78. 
Никон, а один из сподвижников Аввакума и впрямь предлагал хулителям старины огненное испытание: взаправду войти в пламя, - кто не сгорит, тот и прав". The back side of the tragic theater of life was the festive carnival element of Maslenica - a popular prototype of "tomfoolness" of the new era ${ }^{25}$. It should be noted that the orientation on the model of the "prophet" ("priest") and "holy fool" in writers' self-reception remains relevant. If we take as an example the typologically similar transitional eras of the $19^{\text {th }}-20^{\text {th }}$ centuries and the $20^{\text {th }}$ century, then the central role was played by symbolists, especially in the theory of theurgy, and then in the prophecies of the coming tempest ("Vozmezdie" by A. Blok). Only in such parameters A. Solzhenitsyn accepted himself, relied on biblical symbols in self-identification. In particular, in his autobiographical "The Oak and the Calf", compares his battle with the totalitarian state with the battle of David and Goliath, and also sees the role of Lev Tolstoy as the moral authority of the new era. He uses the position of the priest and Yu. Mamleev, a writer, differs in his creative setting, in his works of "metaphysical realism", designed to discover the mythical ways of creativity and the global cultural transition of the $20^{\text {th }}$ century.

The archetype of the "holy fool" was realized in works and self-reflection by V. Khlebnikov, O. Kruchenykh, O. Mandelstam, Anna Akhmatova (the image of "city mad woman" as a self-characterization), K. Vaginov, D. Kharms, and Ven. Yerofeyev, A. Sinyavsky, Vik. Yerofeyev, V. Popov, D. Galkovsky, in poet-ironists' works and others. Once again, we emphasize that these models are in the sacral discourse, and that the pattern that A. Toynbee designates as a "savior" and relates its appearance to the moment of transience, in Russian culture, it is universal in its literary entirety. According to A. Panchenko's fair remark, the writers in Russia have been referred to as "secular saints" from the time of the secularization. From here comes the programme and self-reflective character of "Pushkin's" speeches of F. Dostoevsky and A. Blok, the expectation of the answers to the urgent contemporary questions from the literature, constant mythologisation and sacralisation of the writers' figures, use of the sacral archetypes in self-reception (e.g. motives of Christ's Carrying the Cross and Golgotha in works of M. Bulgakov, B. Paternak, E. Kercnovskaya, O. Volkov and others), and finally, painful disputes about the fate of literaturecentricity itself and the status of the writer in the transitional epoch of the cultural fracture of the $20^{\text {th }}-21^{\text {st }}$ century. If we return to the classification, proposed by A. Toynbee, and apply it to the experience of self-reflection of Russian literature, we can conclude that two examples - "hermit" and "transfigured" - received in this context demonstrative modifications.

${ }^{25}$ Исупов К.Г. Становление русской диалогической культуры в ситуации исторического перехода (Москва и Петербург на рубеже XVII-XVIII веков) / К.Г. Исупов // Переходные процессы в русской художественной культуре: Новое и Новейшее время / отв. ред. Н.А. Хренов: Гос. ин-т искусствознания МК РФ; Научн. совет «История мировой культуры» РАН. - М. : Наука, 2003. - С. 248-249 
The meaning of "outcast" is the most appropriate for the recluse. This model of creator's interpretation and self-identification is considered by Yu. Lotman and B. Uspensky as the major characteristic of national culture. Their studies are based on the material of the literature of the pre-Petrine period, but the results are projected on the fate of the intelligentsia as a whole ${ }^{26}$. This guideline, it seems, could be supplemented by another sense, which also took shape in the transitional epoch of the $17^{\text {th }}-18^{\text {th }}$ centuries within the framework of the opposition of "private man" and "public man". Unrestrained privacy, adventurism, the playing principle are characteristics for the hero of the baroque, and the collection - already a sign of the hero of classicism. As much as in Russian literature both styles developed in close weave, their guidelines can be combined in a bizarre way: "Poet in the $18^{\text {th }}$ century also feels like a state man. For example, Derzhavin's civil service and his poetic activities, poetic vocations, seem to balance and are worth one another. Karamzin, cultivating the image of an individual "game" man, who published a collection of poems under the expressive name "My Trifles", was not less a state historian. Both Derzhavin and Karamzin, in spite of oppositional statements, are inseparably linked to official statehood ${ }^{27,}$. The fact of the writers' reflections on the orientations of self-identification is a testimony to the growth of the personality commencement in the literature, typical for the transitional $17^{\text {th }}$ century.

As for the orientation of the "private", "game" person, it eventually began to dominate; firstly, in connection with the crisis of the classicists' statements, secondly, with the change of the view of the world and the formation of romantic guidelines. One of the incarnations of the romantic picture of the world was the image of an "extra person", which served as a guideline for further self-identification. In each of the subsequent periods of the development of literature and in the interpretation of specific styles (romanticism, modernism, avant-garde, postmodernism), this model was actualized and acquired specific properties in each of them. For example, researchers consider the privacy and self-orientation of the individual-creator as the dominant feature of the underground of 1960-1970s, that had an effected the self-reflection: in literature manifests (editorial article of the journal "Kamera Skhovu”, 1984) and in authomethadescriptions, portraits of like-minded artists. Thus, S. Savitsky insists that the literary work was seen as "private" by unofficial writers, and the readers also expected privacy in their works. Privacy was the principle of social organization of non-official literature. This idea was expressed in the developed

26 Лотман Ю. Роль дуальных моделей в динамике русской культуры (до конца XVIII века). // Ю. Лотман, Б. Успенский // Избранные труды. - М., 1994. - Т. 1. Семиотика истории. Семиотика культуры. - С. 219-253.

27 Бойко М.Н. Россия XVIII-XIX веков: цивилизационный поворот и культурная самобытность / М.Н. Бойко // Переходные процессы в русской художественной культуре: Новое и Новейшее время : сборник научных ст. / Отв. ред. Н.А. Хренов; Гос. ин-т искусствознания МК РФ; Научн. совет «История мировой культуры» РАН. - М.: Наука, 2003. - С. 198. 
system of rhetorical means: the themes of texts, their genre features, as well as in the choice of characters.

Scientists identify models of artists' self-identification that are the most fully realized in Russian culture. The researchers referred to them such models as the "traveler" and then a modified model of "transformed". In some modifications, these two models are also associated with sacral discourse and the mythological plot of initiation: the traveler seeks lost paradise, the city, reflects the divine ideal; and the "transfigured" experiences an internal reprogramming after the trials he has survived, and it takes place in accordance with the traditions of spiritual insight. The M. Berdyayev's characteristics of this type of artist can be considered as a striking manifestation of the selfreflection of literature and philosophy of the Silver Age, which reflected the transient artistic thinking: "The type of traveler is so characteristic for Russia and so wonderful. The traveler is the freest man on earth. He walks the earth, but his element is airy, he does not root into the earth, he has no down-to-earth approach. The traveler is free from the "world" and all the hardship of the earth and the earthly life is reduced to him, to a small bag on his shoulders ${ }^{28}$ ". In Berdyayev's perception, the concept of "travelling” has the most important characteristics of universal, reflects the anxiety of the national spirit, its passionarity and transitivity, and as travelling is conditioned by spiritual search, it reflects the mechanisms of national desires.

A similar example of author's reception of Russian philosophy and literature of the Silver Age using the concept of "spiritual travel" is the characteristic of $\mathrm{V}$. Solovyov by E. Trubetsky, who is known to have had the strongest influence on the formation of the symbolists' identity: "By his spiritual appearance he reminds the type of traveler wandering around Rus', who seeks the highest Jerusalem, and therefore spends his life in walking around all the impenetrable space of the earth, honoring and visiting all the holy things, but does not stop here. In such a life, the material matters do not take up much space: for travelers they represent everything only in a small bag behind their shoulders ${ }^{29}$ ". Note that throughout the $20^{\text {th }}$ century in the Russian literature the concept of "travel" as a guideline for self-identification is actively manifested in works of many writers: M. Rubtsov, J. Brodsky, in the 1970s - 2000s it is a leading one in selfreflection close to the author's characters of the poem "Moscow-Petushki" by Ven. Yerofeyev, "Five Rivers of Life" by Vik. Yerofeyev, the novel "The Way of Muri" by V. Boyashov, the narrator in travesty travels V. Berezin and others.

Researchers consider the similarity and difference between the guidelines of the "traveler" and "transformed". The point of intersection between them is the sacral discourse: "The purpose of the traveler is associated with joining the

28 Бердяев Н. Судьба России. (Опыты). Очерки по психологии войны и национальности / Николай Бердяев. - М., 1918. - С. 12.

${ }_{29}$ Трубецкой Е. Миросозерцание В.С. Соловьева: в 2 т. / Евгений Трубецкой. - М.: Медиум, 1995. - Т. 1.- С. 113. 
sacred world and the transformation of the profane into the sacred world. Transformation should be understood as a leap or transition into a sacral world, which is the essence of transitional rites ${ }^{30}$ ". Illustrating these statements, M. Khrenov again turns to self-knowledge of the Russian culture of the Silver Age, to the characterization of E. Trubetskoy as an image and global guideline of the national classics. The philosopher speaks about the shining of the sacral "Divine Light" in the art of the word: "Consciously or unconsciously, the greatest representatives of the Russian national genius have always sought this light, which heals from within and transforms both spiritual and physical life. Universal healing in general transformation - in various modifications we find this idea in great artists' works, in Gogol, Dostoyevsky, even though in a distorted, rationalized form of Tolstoy, and in thinkers - Slavophiles such as Fiodorov, Solovyov and many of his followers". It is stated that in the selfreflection of the literature of the new transitional period of the turn of the $20^{\text {th }}-$ $21^{\text {st }}$ centuries, the efficacy and the global archetype of the transfigured creator in the twentieth-century art is emphasized. Thus, in this connection, writer and artist Maksim Kantor characterizes in his meta-essay the "apostolate" of A. Blok, M. Bulgakov, B. Pasternak and emphasizes that in the works by Mayakovsky the similar transformation as reached the extreme avant-garde forms and borders, when romantic poet, who suffers from the loneliness and disorder with the world, it turns into the servant of the utopian idea and demonstrates greatness in the refusal from generally accepted in the surrounding of masters guidelines of self-identification: "Early Mayakovsky promised much, but didn't really imagine how to fulfil these abstract promises $<\ldots>$ The miracles don't happen. Miracle happened after he refused from poetry $<\ldots>$ When he began to make "Okna ROCTA », <..> he had become truly great. So he wrote his most important things in which he described the image of an ideal society; this is no longer poetry - but a programme of building a utopian society. In doing this, he found himself equal not to his contemporary poets, but to Tomas Mor and Campanelli. <...> "Good!" presents a plan for community building $<\ldots>$ There is only one poem in Russian poetry of the same construction scale just as pretentious in describing the ways of the Russian society and the role of the person in its construction - these is Pushkin's "Bronze Horseman ${ }^{31}$ ". The portrait of Mayakovsky painted in the provocative way is aimed at the regular review of the literary hierarchy, at the discussion with "postconstructive" destructive conceptions, which itself reflects the author's thinking. We also add that the unexpected, paradoxical characteristics of the poet are at the same time the self-reflection of the literature of the 2000s,

30 Хренов Н.А. Культура в эпоху социального хаоса / Н.А. Хренов. - М.: Едиториал УРСС, 2002. - С. 164.

${ }^{31}$ Кантор М. Апостол революции (В.В. Маяковский) / М. Кантор // Литературная матрица. Учебник, написанный писателями. XX век: Сборник. - 2-е изд. - СПб.:Лимбус Пресс, ООО «Издательство К. Турбина», 2011. - С. 233-234. 
which outlines its rejection of the world of commerce again, that has been turned upside down, in which the hateful characters "The Bedbug" and "The Bathhouse" have won; it is represented the longing for a true "apostle" and the sacrificial transformed image of the creator; suspicions that the current humanity is not able to give birth to the figure similar to Mayakovsky: "He has gone - and Russia left without its poet ${ }^{32,}$. As we can see, the study of the transitional thinking allowed the researchers to distinguish the characteristic models of interpretation of the creativity and self-identification of the creator, as well as to identify their systemic relations. The credibility of this paradigm is confirmed by the fact that the identified guidelines in the literature of one particular epoch appear in the art of other crucial periods, demonstrating universality and efficiency of this code of interpretation of transitional time and literature metamorphoses. The use of the self-identification paradigm can be effective in studying the formation of a new literary identity in Russian literature of the $20^{\text {th }}-21^{\text {st }}$ centuries.

\section{CONCLUSIONS}

Studies of self-consciousness of literature combine and complement approaches of literary criticism, culturology, sociology and psychology. The intensified dynamics of self-consciousness of literature coincide with metascientific reflection, representing the transition to a new stage of the development of culture. Its key parameters are dialogism and existentialism, which stimulate reflection and self-consciousness.

The culture direction of the study of literary self-consciousness reveals the connection of self-reflection with the types of culture and their change, peculiarities of certain epochs, the dialogue of different culture languages, the relations between art and everyday life. The mission of literature is to generate super-senses, to produce a code of interpretation for complex phenomena.

Self-reflection of literature can be considered as a unifying beginning in a discrete picture of the word's art of the twentieth century. The artistic consciousness of this era combined the orientations of the poetics of artistic modality with the reinterpretations and renewed traditions of rhetorical poetics that actualized the concept of the canon.

\section{SUMMARY}

The article studies the theoretical aspect of the dynamics of writer's selfconsciousness at the end of the $20^{\text {th }}$ century, which has a clear tendency to intensify and deepen at the turn of the centuries. The paper presents an attempt to analyze the transition mechanism, to examine how its components affect the

32 Кантор М. Апостол революции (В.В. Маяковский) / М. Кантор // Литературная матрица. Учебник, написанный писателями. XX век: Сборник. - 2-е изд. - СПб. : Лимбус Пресс, ООО «Издательство К. Турбина», 2011. - С. 232. 
form and content of authors' self-identification and how the interpretative and representative models of self-identification characteristic to all literatures in periods of crisis disturbances are created by their means. By identifying the types and forms of self-reflection characteristic of these periods, much attention is given to revealing the national originality in implementation of the mechanisms of transitional thinking in close connection with models of selfconsciousness. The article also proves that radical changes awaken the activity of archaic, archetypes, traditional models, which have already exhausted themselves in the past, but have settled in the depths of the collective unconscious in the context of transitional artistic thinking. Certain mythological antinomies are actualized ("priest”, "tomfool”, "heretic”, "marginal”, "outcast”, "vozhd"” etc.). The outlined circle of archetypes confirms an idea of inversion type of Russian culture involving two contrasting poles and their conversion under the influence of the mechanism of abrupt change.

\section{REFERENCES}

1. Абашева М.П. Литература в поисках лица (Русская проза конца XX века: становление авторской идентичности) / Марина Петровна Абашева. - Пермь : Изд-во Пермского университета, 2001. - 320 с.

2. Барт Р. Литература и метаязык / Ролан Барт // Избранные работы: Семиотика. Поэтика / [Пер. с фр. С.Н. Зенкина; сост., общ. ред. и вступ. ст. Г.К. Косикова]. - М. : Прогресс, 1994. - С. 131-132.

3. Бердяев Н. Судьба России. (Опыты). Очерки по психологии войны и национальности / Николай Бердяев. - М., 1918. - 240 с.

4. Бойко М.Н. Россия XVIII-XIX веков: цивилизационный поворот и культурная самобытность / М.Н. Бойко // Переходные процессы в русской художественной культуре: Новое и Новейшее время : сборник научных ст. / Отв. ред. Н.А. Хренов; Гос. ин-т искусствознания Мин-ва культуры РФ; Научн. совет «История мировой культуры» РАН. - М. : Наука, 2003. C. 195-225.

5. Иванов В. Чурленис и проблема синтеза искусств / Иванов В. // Бездны и межи. - М. : изд-во «Мусагетъ», 1916. - С. 313-347.

6. Исупов К.Г. Становление русской диалогической культуры в ситуации исторического перехода (Москва и Петербург на рубеже XVIIXVIII веков)/ К.Г. Исупов // Переходные процессы в русской художественной культуре: Новое и Новейшее время / отв. ред. Н.А. Хренов: Гос. ин-т искусствознания МК РФ; Научн. совет «История мировой культуры» РАН. - М. : Наука, 2003. - С. 245-281.

7. Кантор М. Апостол революции (В.В. Маяковский) / М. Кантор // Литературная матрица. Учебник, написанный писателями. XX век: Сборник. - 2-е изд. - СПб.:Лимбус Пресс, ООО «Издательство К. Турбина», 2011. - С. 233-234. 
8. Кеба А.В. Метатекст, метароман и проблема отношения искусства к действительности в литературе XX века / А.В. Кеба // Поетика художніх форм у сучасному сприйнятті. Науковий збірник. - Одеса : Одеський національний університет імені I.I. Мечнікова: «Астропринт», 2012. - С. 6-16.

9. Кривцун О.А. Смысл творчества в интерпретации художника XX века (Знаки переходного сознания) / О.А. Кривцун // Переходные процессы в русской художественной культуре: Новое и новейшее время /Отв. ред. Н.А. Хренов; Гос. ин-т искусствознания М-ва культуры РФ; Науч. совет «История мировой культуры» РАН. - М. : Наука, 2003. - С. 423 -453.

10. Лосев А. Эстетика Возрождения / А. Лосев. - М.: «Мысль», 1978. $-623 \mathrm{c}$.

11. Лотман Ю. Роль дуальных моделей в динамике русской культуры (до конца XVIII века). // Ю. Лотман, Б. Успенский // Избранные труды. М., 1994. - Т. 1. Семиотика истории. Семиотика культуры. - С. 219-253.

12. Маритен Ж. Ответственность художника / Жак Маритен // Самопознание европейской культуры ХХ века. - М.,1991. - С. 171-207.

13. Московичи С. Машина, творящая богов /Серж Московичи. - М.: Центр психологии и психотерапии, 1998. - 560 с.

14. Панченко А. Русская культура в канун петровских реформ/ А. Панченко. - Л. : Наука, Ленинградское отделение, 1984. - 205 с.

15. Степанов Ю. Константы: словарь русской культуры / Ю. Степанов. - Изд. 2-е испр., доп. - М. : Академический проект, 2001. - 900 с.

16. Тойнби А.Дж. Постижение истории / А.Дж. Тойнби. - М.:АйрисПресс, 2002. - 640 с.

17. Трубецкой Е. Миросозерцание В.С. Соловьева : в 2 т. / Евгений Трубецкой. - М.: Медиум, 1995. - Т. 1.- 604 с.

18. Хренов Н.А. Культура в эпоху социального хаоса / Н.А. Хренов. М. Едиториал УРСС, 2002. - 448 с.

19. Ястребова Н.А. Искусство советского времени в проблемном поле европейского XX века / Н.А. Ястребова // Переходные процессы в русской художественной культуре: Новое и Новейшее время / Отв. ред. Н.А. Хренов ; Гос. ин-т искусствознания М-ва культуры РФ; Научн. совет «История мировой культуры» РАН. - М.: Наука, 2003. - С. 454-471.

20. Kawiecki P. Post-modernism - From Clown to Priest / P. Kawiecki // The Subjuect in Postmodernism. - Ljubljana, 1989. - Vol. 2. - P. 101-182.

\section{Information about the author: Shtepenko 0.}

Doctor of Philology, Associate Professor, Professor at the Department of World Literature and Culture named after professor O. Mishukov of the Kherson State University 40 rokiv Zhovtnya str., Kherson, 73000, Ukraine 